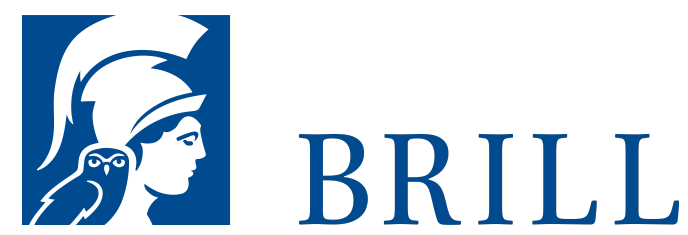

\title{
The Usefulness of Truth
}

\section{An Enquiriy Concerning Economic Modelling}

\section{Author: Simon Deichsel}

Deichsel attempts to justify a normative role for methodology by sketching a pragmatic way out of the dichotomy between two major strands in economic methodology: empiricism and postmodernism. It is important to understand that this book is about methodology and this means that it does not add another recipe with prescriptions as to how economics needs to change in order to become a 'better' or 'proper' science. Instead, several methodological approaches are discussed and assessed concerning their aptness for theory appraisal in economics. The book starts with presenting the most common views on methodology (i.e. empiricism and postmodernism) and provides reasons why they are each ill-suited for giving methodological prescriptions to economics. Finally, a pragmatic approach that can do this is sketched out.

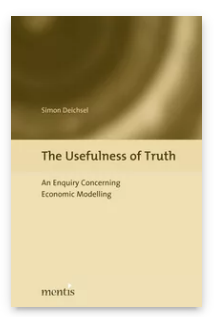

Pages: 239

Seiten

Language:

English

Subjects:

General,

Philosophy

Publisher: Brill | mentis

E-Book (PDF)

Released online:

o1 May 2012

ISBN: $978-3-$

95743-967-3

List price

USD $\$ 60.00$

Paperback

Publication date:

O1 May 2012

ISBN: 978-3-

89785-754-4

List price

USD \$6o.oo 
For more information see brill.com

Order information: Order online at brill.com +44330 333 0049 | customerservices@brill.com Submission information: brill.com/authors

Titles published by Brill | Fink, Brill | mentis or Brill | Schöningh: +49(o)715413279216| brill@brocom.de 